TAHUN AJARAN : 2020/2021

\title{
THE INFLUENCE OF THE ROLE OF THE HOMEROOM TEACHER IN LEARNING FROM HOME (BDR) ON THE ACTIVENESS OF CLASS XI STUDENTS IN MAN 1 JOMBANG ACADEMIC YEAR: 2020 / 2021
}

\author{
Erma Rahmawati \\ M AN 1, Kabupaten Jombang \\ E-mail: ermaabong@gmail.com
}

\begin{abstract}
ABSTRAK
Pelaksanaan KBM di madrasah sejak bulan Maret 2020 mengalami perubahan dikarenakan ada pandemi Covid-19, pemerintah telah menetapkan konsep BdR (Belajar dari Rumah) diseluruh jenjang pendidikan. Penelitian ini bertujuan ingin mengetahui pengaruh peran wali kelas dalam kegiatan BDR terhadap keaktifan peserta didik kelas XI MAN 1 J ombang. Metode yang digunakan pada penelitian ini adalah metode penelitian kuantitatif. Teknik pengumpulan data yang peneliti gunakan adalah observasi, wawancara, dokumentasi, dan angket. Untuk analisa data menggunakan uji autokorelasi Durbin-Watson, dan Uji Simultan F. Hasil penilitan menunjukkan bahwa terdapat pengaruh peran wali kelas terhadap keaktifan peserta didik kelas XI MAN 1 Jombang sebesar 69,2\%
\end{abstract}

Kata Kunci : Wali Kelas, Daring, Keaktifan

\section{ABSTRACT}

The implementation of teaching and learning activities in madrasas since March 2020 has changed due to the Covid-19 pandemic, the government has established the concept of BDR (Learning from Home) at all levels of education. This study aims to determine the extent of the influence of the role of the homeroom teacher in BdR activities on the activeness of class XI students in MAN $1 \mathrm{~J}$ ombang. The method used in this research is quantitative research methods. Data collection techniques that researchers use are observation, interviews, documentation, and questionnaires. For data analysis using the Durbin-Watson autocorrelation test, and the Simultaneous $\mathrm{F}$ test. The results showed that there was an influence on the role of homeroom teacher on the activeness of class XI students in MAN 1 J ombang, amounting to $69.2 \%$.

Keywords : Homeroom Teacher, Online, Activeness

\section{PENDAHULUAN}

Proses pembelajaran pada hakekatnya merupakan proses interaksi antara guru dengan siswa yang didalamnya berisi aktivitas peserta didik melalui berbagai interaksi dan pengalaman belajar yang dialami oleh keduanya. Keaktifan belajar siswa merupakan salah satu unsur dasar yang penting bagi keberhasilan proses pembelajaran. Dalam Kamus Besar Bahasa Indonesia aktif berarti giat dalam bekerja atau berusaha. Kegiatan bekerja dan berusaha dilakukan oleh siswa dalam proses pembelajaran sesuai dengan materi pelajaran yang disampaikan oleh guru. Keaktifan adalah kegiatan yang bersifat fisik maupun mental, yaitu berbuat dan berfikir sebagai suatu rangkaian yang tidak dapat dipisahkan (Sardiman, 2001 : 98).

Yamin (2007: 77) menyebutkan, keaktifan siswa dalam proses pembelajaran dapat merangsang dan mengembangkan bakat yang 
dimilikinya, berfikir kritis, dan dapat memecah permasalahan-permasalahan dalam kehidupan sehari-hari.

Kegiatan belajar mengajar di madrasah sejak bulan Maret 2020 mengalami perubahan karena adanya pandemi Covid-19. Pemerintah telah menetapkan konsep BdR (Belajar dari Rumah) diseluruh jenjang pendidikan termasuk jenjang Madrasah Aliyah, seluruh satuan pendidikan harus melaksanakan segala bentuk kegiatan akademik di rumah, kondisi ini sangat berbeda jauh bila dibandingkan dengan kegiatan belajar secara tatap muka.

Dari hasil pengamatan menunjukkan bahwa selama kegiatan BdR terjadi kesenjangan antara guru dengan peserta didik, karena guru tidak dapat mengamati secara langsung aktifitas peserta didik selama pembelajaran, maka dibutuhkan peran wali kelas dalam membantu kesenjangan tersebut.

Menurut Soetjipto (2011: 102) wali kelas merupakan personal sekolah yang ditugasi untuk menangani masalah-masalah yang dialami oleh siswa yang menjadi binaannya. Ini berarti bahwa seorang wali kelas harus memimpin kelasnya yang tidak hanya terbatas dalam kelas tetapi juga di luar kelas.

Tugas dari wali kelas sebagaimana tertuang dalam lampiran Peraturan Menteri Pendidikan Dan Kebudayaan Republik Indonesia Nomor 15 Tahun 2018 antara lain : mengelola kelas yang menjadi tanggungjawabnya dan berinteraksi dengan orang tua/ wali peserta didik.

Pelaksanaan BdR di MAN 1 Jombang selama bulan Maret sampai dengan Juli 2020 dapat berjalan dengan lancar. Prosedur yang dijalankan adalah guru mapel mengabsen setiap hari kehadiran peserta didik, jika ada yang tidak mengikuti atau tidak mengumpulkan tugas dan lain-lain maka guru tersebut akan melaporkan dan akan ditulis dalam jurnal yang setiap minggu dishare ke wali kelas untuk mendapatkan tindak lanjut. Jika ada peserta didik mengalami masalah maka wali kelas bersama Tim Bimbingan Konseling (BK) akan segera mengadakan home visit dengan memperhatikan protokol kesehatan sehingga permasalahan segera bisa diselesaikan.
Dari uraian diatas, maka peneliti ingin mengetahui apakah ada pengaruh peran wali kelas dalam kegiatan Belajar dari Rumah (BdR) terhadap keaktifan peserta didik kelas XI MAN 1 J ombang.

\section{KAJIAN TEORI \\ Peran Wali Kelas}

Kusuma Albertus (2007 : 247) mendefinisikan wali kelas sebagai guru bidang studi tertentu yang mendapat tugas tambahan sebagai penanggung jawab dinamika pembelajaran di dalam kelas tertentu. Wali kelas memiliki peran seperti kepala keluarga dalam kelas tertentu, menciptakan kondisi dan lingkungan yang kondusif sehingga proses belajar mengajar berjalan dengan baik.

Peran wali kelas sebagai kepala keluarga dalam kelas tertentu sangat dibutuhkan pada saat peserta didik kelas binaannya mengalami berbagai problematika, sebagai contoh ada peserta didik yang kurang respon terhadap salah satu mata pelajaran, atau kurang respon terhadap salah satu guru mata pelajarannya, maka peran wali kelas sebagai kepala keluarga dapat berinteraksi dengan peserta didik dengan berbincangbincang dengan menyesuaikan karakter peserta didik untuk menggali sumber permasalahan yang sedang terjadi dan mencari solusi bersama.

Seorang wali kelas merupakan orang tua pertama di madrasah, seorang wali kelas juga dapat berperan sebagai seorang fasilitator, motivator dan mengetahui seluk beluk permasalahan siswa baik secara pribadi, sosial, dan akademis. 1. Peran wali kelas sebagai fasilitator. Seorang wali kelas harus bisa menjalin hubungan kemitraan dengan siswa, hubungan kemitraan antara guru dengan siswa, guru bertindak sebagai pendamping belajar para siswanya dengan suasana belajar yang demokratis dan menyenangkan agar siswa dapat belajar dengan baik.

2. Peran wali kelas sebagai motivator. Seorang wali kelas harus mampu mendorong siswanya agar lebih maju dan semangat dalam pembelajaran, memberikan wawasan yang lebih luas, memberikan bekal untuk masa depan siswanya.

3. Peran wali kelas sebagai problem solving. Dalam hal ini seorang wali kelas harus mengetahui permasalahan siswanya baik 
pribadi, sosial, dan akademis. a] Pribadi. Seorang wali kelas harus mengetahui karakter dan sifat anak sehingga dia bisa memberikan pelayanan sesuai dengan sifat anak tersebut. b] Sosial. Seorang wali kelas harus mengetahui hubungan sosial anak dengan teman sebayanya, dengan gurunya, dan orang tuanya agar wali kelas dapat menyesuaikan dengan kondisi yang sebenarnya. c] Akademis. Seorang wali kelas harus mengetahui kemampuan, prestasi siswanya sehingga wali kelas bisa memberikan motivasi sesuai dengan masalah akademis dalam kemampuan siswanya (Djamarah, 2017 : 48-49).

\section{Kegiatan Belajar dari Rumah (BdR)}

Mekanisme Pembelajaran dan Penilaian Madrasah dalam Masa Darurat Pencegahan Penyebaran Covid-19 tertuang pada Surat Direktorat Jenderal Pendidikan Islam Kementerian Agama Republik Indonesia pada nomor 3 yang berbunyi : Proses Belajar dari Rumah dilaksanakan dengan ketentuan sebagai berikut:

a. Penentuan masa atau jangka waktu belajar dari rumah untuk madrasah mengikuti ketentuan yang ditetapkan oleh Pemerintah daerah/ Gubernur setempat, termasuk perubahan perpanjangan masa belajar dari rumah yang menyesuaikan pada kondisi masing-masing daerah.

b. Aktivitas dan tugas pembelajaran pada masa Belajar dari Rumah dapat bervariasi antarsiswa, sesuai minat dan kondisi masing-masing, termasuk mempertimbangkan kesenjangan akses/ ketersediaan fasilitas belajar di rumah. Pemberian tugas pembelajaran wajib mempertimbangkan konsep belajar dari rumah, yaitu sebagai usaha memutus mata rantai penyebaran Covid-19, oleh karena itu beban tugas yang diberikan agar dipastikan dapat diselesaikan oleh siswa tanpa keluar rumah dan tetap terjaga kesehatan, serta cukupnya waktu istirahat untuk menunjang daya imunitas siswa;

c. Belajar dari Rumah melalui pembelajaran daring/ jarak jauh dilaksanakan untuk memberikan pengalaman belajar yang bermakna bagi siswa, tanpa terbebani tuntutan menuntaskan seluruh capaian kurikulum untuk kenaikan kelas maupun kelulusan. Madrasah dapat menyelenggarakan belajar dari rumah dengan memanfaatkan aplikasi e-learning madrasah melalui https:/ / elearning. kemenag.go.id/web dan/atau aplikasi daring lainnya;

d. Belajar dari Rumah lebih menitikberatkan pada pendidikan kecakapan hidup, misalnya pemahaman mengatasi pandemi Covid-19, penguatan nilai karakter atau akhlak, serta ketrampilan beribadah siswa di tengah keluarga;

e. Bukti atau produk aktivitas Belajar dari Rumah diberi umpan balik yang bersifat kualitatif dan berguna dari guru, tanpa diharuskan memberi skor/ nilai kuantitatif.

\section{Keaktifan Belajar}

Keaktifan yang dimaksud pada penelitian ini adalah keaktifan belajar peserta didik. Belajar tidaklah cukup hanya dengan duduk dan mendengarkan atau melihat sesuatu. Belajar memerlukan keterlibatan fikiran dan tindakan peserta didik sendiri. Keaktifan belajar terdiri dari kata "Aktif" dan kata "Belajar". Keaktifan berasal dari kata aktif yang mendapat imbuhan ke-an menjadi keaktifan yang berarti kegiatan, Keaktifan belajar berarti suatu usaha atau kegiatan yang dilakukan dengan giat belajar.

Setiap peserta didik memiliki gaya belajar yang berbeda-beda. Karena itu setiap peserta didik perlu mendapatkan bimbingan belajar yang berbeda pula sehingga seluruh peserta didik dapat berkembang sesuai dengan tingkat kemampuannya. Keaktifan peserta didik dapat kita lihat dari keterlibatan peserta didik dalam setiap proses pembelajaran, seperti pada saat mendengarkan penjelasan materi, berdiskusi, membuat laporan tugas dan sebagainya. Keaktifan belajar peserta didik dapat dilihat dalam hal: Turut sertanya dalam mengerjakan tugas, terlibat dalam proses pemecahan masalah, bertanya kepada teman satu kelompok atau guru apabila tidak memahami persoalan yang sedang dihadapinya, melaksanakan diskusi kelompok sesuai dengan petunjuk guru, dan mampu mempresentasikan hasil kerjanya.

Dari berbagai pengertian di atas, dapat 
disimpulkan bahwa keaktifan belajar adalah suatu keadaan dimana peserta didik dapat melakukan berbagai kegiatan yang aktif baik jamani dan rohaninya seperti memperhatikan pembelajaran di kelas, memecahkan masalah, bekerja sama dalam kelompok, mengemukakan pendapat, guna membantu memperoleh pemahaman kepada dirinya sendiri terkait materi yang dibahas.

Keaktifan peserta didik dalam proses pembelajaran dapat merangsang serta mengembangkan bakat yang dimilikinya, peserta didik juga dapat berlatih untuk berfikir kritis dan dapat memecahkan permasalahan-permasalahan dalam kehidupan sehari-hari.

Sedangkan menurut Gagne dan Briggs (dalam Martinis, 2007:84) faktor faktor tersebut diantaranya adalah sebagai berikut : memberikan dorongan atau menarik perhatian peserta didik, menjelaskan tujuan intruksional (kemampuan dasar kepada peserta didik), mengingatkan kompetensi belajar kepada peserta didik, memberikan stimulus (masalah,topik dan konsep yang akan dipelajari), memberi petunjuk kepada peserta didik cara mempelajarinya, memunculkan aktivitas, partisipasi peserta didik dalam kegiatan pembelajaran, memberi umpan balik (feed back), melakukan tes singkat diakhir pembelajaran, dan menyimpulkan setiap materi yang disampaikan di akhir pelajaran.

\section{Kerangka Konseptual}

Berdasarkan uraian diatas, maka peneliti menduga terdapat pengaruh antara variabel $(X)$ terhadap variabel $(Y)$, dengan kata lain diduga terdapat pengaruh positif antara peran wali kelas terhadap keaktifan peserta didik mengikuti BDR. Yang digambarkan dalam diagram berikut : Keterangan:

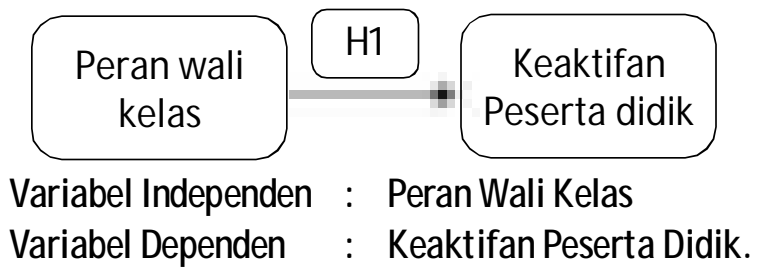

\section{METODE PENELITIAN}

Metode yang digunakan pada penelitian ini adalah metode penelitian kuantitatif yaitu metode penelitian, untuk meneliti pada tingkat populasi atau sampel tertentu, pengumpulan data menggunakan instrumen penelitian, analisis data bersifat statistik, dengan maksud untuk mendeskripsikan dan menguji hipotesis yang telah ditetapkan (Sugiyono, 2013 : 36).

Penelitian ini peneliti menggunakan pendekatan kuantitatif, karena penelitian ini peneliti ingin mengetahui bagaimana pengaruh antara dua variabel yaitu variabel bebas dan variabel terikat.

\section{Lokasi dan Waktu Penelitian}

Adapun lokasi penelitian ini adalah di MAN 1 Jombang, Jalan Dr. Wahidin Sudiro Husodo Nomor 02 Jombang dengan obyek penelitian pada kelas XI disemua Jurusan, sedangkan waktu penelitian ini dimulai pada bulan Juni sampai dengan bulan Agustus 2020.

\section{Populasi dan Sampel Penelitian}

Populasi adalah "wilayah generalisasi yang " terdiri atas: obyek/subyek yang mempunyai kualitas dan karakteristik tertentu yang ditetapkan oleh peneliti untuk dipelajari dan kemudian ditarik kesimpulannya". (Sugiono, 2013 : 61).

Populasi yang dimaksudkan dalam penelitian ini adalah keseluruhan subjek yang akan menjadi titik perhatian dalam pelaksanaan penelitian yang nantinya akan dipelajari serta ditarik kesimpulannya. Adapun Populasi dalam penelitian ini adalah seluruh peserta didik kelas XI MAN 1 Jombang.

Menurut Sugiono (2013: 61) sampel adalah bagian dari jumlah dan karakteristik yang dimiliki oleh populasi. Sampel harus benar-benar representatif.

Berdasarkan pendapat diatas, peneliti menyimpulkan sampel adalah bagian dari populasi yang akan diteliti. Sampel pada penelitian ini menggunakan populasi. Selanjutnya untuk mengambil sampel dalam penelitian ini penulis berpedoman pada pendapat Arikunto (2002 : 112) yang menyatakan bahwa "apabila subyeknya kurang dari 100 lebih baik diambil semua hingga penelitiannya berupa penelitian populasi. Selanjutnya, jika subyeknya lebih besar dari 100 maka dapat diambil antara 10-15\% atau $20-25 \%$ atau lebih.

Berdasarkan pendapat di atas, mengingat 
jumlah populasi lebih dari 100 orang, sehingga ditetapkan jumlah sampel sebesar $10 \%$ yaitu $551 \times 10 \%=55,1$ peserta didik (dibulatkan menjadi 55 peserta didik.

\section{Tehnik Pengumpulan Data}

Teknik pengumpulan data yang peneliti gunakan adalah sebagai berikut :

\section{Observasi}

Observasi, dilakukan oleh peneliti dengan melakukan pengamatan tentang femomena yang terjadi di kelas XI MAN 1 J ombang, sebagai tahap awaal pra penelitian, peneliti ingin memastikan bahwa masalah yang akan diteliti adalah sesuai dengan indikator yang akan diukur dalam penelitian ini.

\section{Wawancara}

Peneliti melakukan penggalian informasi tentang fenomena yang terjadi dilapangan dengan melakukan wawancara dalam bentuk pertanyaan kepada waka bidang kurikulum madrasah, guru mata pelajaran dan beberapa peserta didik yang duduk di kelas XI MAN 1 Jombang tahun pelajaran 2020/ 2021.

\section{Dokumentasi}

Dokumentasi adalah "mencari data mengenai hal-hal atau variabel yang berupa catatan transkip, buku, surat kabar, majalah, prasasti, notulen rapat, legger, agenda dan sebagainya".

\section{Angket}

Angket atau kuesioner adalah "daftar pernyataan yang didistribusikan melalui pos untuk di isi dan dikembalikan atau dapat juga dijawab di bawah pengawasan peneliti (Nasution, 2006 : 128)

Berdasarkan hal tersebut angket yang disusun dan dibagikan secara online dengan menggunakan aplikasi google form untuk mendapatkan data penelitian secara obyektif dari peserta didik khusunya pada kelas XI MAN 1 Jombang.

\section{TEMUAN DAN PEMBAHASAN}

Setelah melakukan observasi di lokasi penelitian didapat temuan bahwa wali kelas telah melakukan tugas pokok dan fungsinya dengan baik selama KBM BdR melalui pemantauan secara daring dilanjutkan dengan home visit bagi peserta didik yang bermasalah.

Melalui wawancara kepada waka kurikulum dan sejumlah guru di MAN 1 Jombang didapatkan temuan bahwa proses KBM BdR di MAN 1 J ombang selama pandemi covid 19 dilakukan melalui berbagai media aplikasi daring antara lain : e-learning madrasah, google meet, google form, quizizz, schoology dll.

Sedangkan dari studi dokumentasi didapatkan temuan data keaktifan guru dari rekapan daftar hadir dan jurnal elektronik google form.

Hasil penyebaran angket kepada 55 responden sampel penelitian, didapat temuan bahwa peran wali kelas terhadap keaktifan siswa dalam BdR sangat tinggi. Hal ini dibuktikan dengan hasil rekapan angket no: $1,2,3,5,7,8,10$ ratarata menjawab selalu dan angket no: 4, 6, 8, 11 rata-rata menjawab sering. Temuan lain dari penyebaran angket yaitu tingkat keaktifan siswa dalam KBM BdR tinggi. Ini didapat dari rekapan angket no $12.13,14,15,16,19,20$, 22 rata-rata menjawab sering dan angket no 17 , 18, 21 rata-rata menjawab kadang-kadang.

\section{Uji Kualitas Data \\ Uji Validitas dan Uji Reabilitas}

Uji validitas dilakukan melalui korelasi bivariate antara masing-masing skor item pernyataan dengan total skor variabel pada program SPSS dan membandingkan nilai $r$ hitung dengan nilai $r$ tabel.

Melalui olah data SPSS, diperoleh hasil uji validitas dengan kriteria, $n=54$ dan $r$ tabel $=0,268$. Setiap item pernyataan memiliki nilai $r$ hitung $>$ dari $r$ tabel, yang berarti seluruh item pernyataan variabel Peran wali kelas dinyatakan valid. Setiap item pernyataan memiliki nilai $r$ hitung $>$ dari $r$ tabel, yang berarti seluruh item pernyataan variabel Keaktifan peserta didik dinyatakan valid.

\section{Uji Reliabilitas}

Uji reliabilitas dilakukan dengan melihat nilai Cronbach Alpha $(\alpha)$. Melalui olah data SPSS, diperoleh hasil uji reliabilitas dengan kriteria 
nilai Cronbach Alpha> 0,70 pada tiap-tiap variabel. Ini menunjukkan bahwa masingmasing variabel memiliki nilai cronbach alpha $>$ 0,70 , artinya, seluruh item pernyataan pada masing-masing variabel dinyatakan reliabel.

\section{Uji Asumsi Klasik \\ Uji Normalitas}

Uji ini dapat dilakukan dengan dua cara melalui program SPSS, yaitu dengan analisis grafik dan uji statistik untuk mengetahui distribusi residual terjadi secara normal atau tidak

\section{Analisis Grafik}

Hasil analisis normal probability plot didasarkan pada keputusan bahwa model regresi dikatakan memenuhi asumsi normalitas jika data menyebar disekitar garis diagonal dan mengikuti arah garis diagonal.

Grafik di atas menunjukkan bahwa data

Grafik Normal Probability Plot Keaktifan Peserta Didik

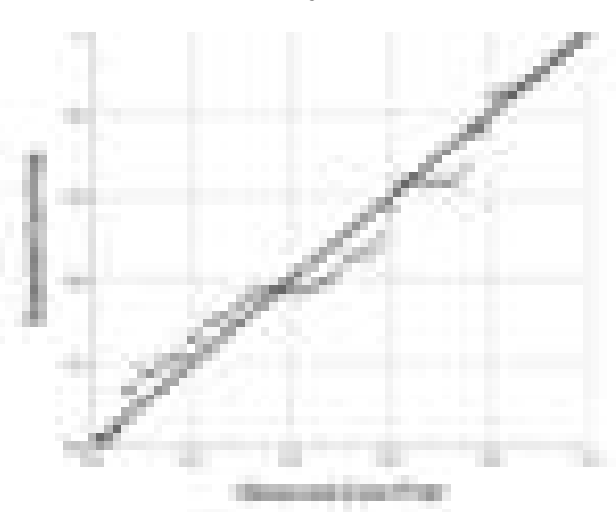

Sumber : Olah Data SPSS, 2020

menyebar di sekitar garis diagonal dan mengikuti arah garis diagonal, maka asumsi normalitas dapat terpenuhi.

\section{Analisis Statistik}

Uji yang digunakan adalah uji nonparametrik Kolmogorov-Smirnov (K-S) dan hasil uji menunjukkan bahwa nilai signifikasi 0,200 $>0,05$. Maka, Ha ditolak dan Ho diterima yang berarti data residual terdidstribusi secara normal. Pernyataan ini sejalan dengan hasil uji analisis dengan grafik normal probability plot. Uji Autokorelasi
Hasil uji autokorelasi dapat dilihat pada nilai Durbin-Watson sebesar 1,793 yang dibandingkan dengan nilai tabel DW dengan signifikasi $5 \%$, jumlah sampel (n) 54 , dan jumlah variabel independen $1(k=1)$.

Hasil perbandingan antara nilai Durbin-

\begin{tabular}{|c|c|c|c|c|c|}
\hline \multicolumn{7}{|c|}{ Model Summary } \\
\hline M odel & $R$ & $\begin{array}{c}R \\
\text { Squar } \\
\mathrm{e}\end{array}$ & $\begin{array}{c}\text { Adjusted } \\
\text { R Square }\end{array}$ & $\begin{array}{c}\text { Std Error } \\
\text { of the } \\
\text { Estimate }\end{array}$ & $\begin{array}{c}\text { Durbin- } \\
\text { Waatson }\end{array}$ \\
\hline 1 & $\begin{array}{c}83 \\
2^{\mathrm{a}}\end{array}$ & 692 & 680 & 1.41753 & 1.793 \\
\hline
\end{tabular}

Keterangan :

a. Predictors: (Constant), Peran Wali Kelas

b. Dependent Variable: Keaktifan Peserta Didik

Watson dengan tabel DW menunjukkan nilai Durbin-Waston 1,793 lebih dari du 1,638 dan kurang dari 4 - 1,638 (4 - du), sehingga melalui dasar keputusan ( $d u<d<4$ - du) maka Ho diterima yang berarti bahwa tidak terjadi autokorelasi (baik positif maupun negatif).

Uji ini digunakan untuk mengetahui bagaimana pengaruh variabel independen terhadap variabel dependen, yaitu peran wali kelas terhadap keaktifan peserta didik. Adapun hasil pengolahan data adalah sebagai berikut :

Tabel Uji F (Simultan)

ANAVA

a. Dependent Variable : Keaktifan Peserta Didik

\begin{tabular}{|r|c|c|c|c|c|}
\hline \multicolumn{6}{|c|}{ Model Summary } \\
\hline Model & $\begin{array}{c}\text { Sun of } \\
\text { Square }\end{array}$ & df & $\begin{array}{c}\text { Mean } \\
\text { Square }\end{array}$ & $F$ & Sig. \\
\hline 1 Regresion & 230.354 & 2 & 115.177 & 57.319 & $.000^{\mathrm{b}}$ \\
$\begin{array}{c}\text { Residua 1 } \\
\text { Total }\end{array}$ & 102.479 & 51 & & & \\
\hline
\end{tabular}

b. Predictors: (Constant), Peran Wali Kelas. Sumber: Olah Data SPSS, 2020

Tabel Uji Simultan di atas menunjukkan bahwa nilai $F$ hitung sebesar 57,319 > F tabel sebesar 3,18 dan nilai signifikasi $0,000<0,05$. Ini berarti bahwa Ho ditolak dan Ha diterima yang menyatakan bahwa variabel peran wali kelas ( $X)$ berpengaruh terhadap variabel Keaftifan 
Peserta Didik (Y).

\section{PENUTUP}

\section{Simpulan}

Kesimpulan penelitian ini adalah peran wali kelas dalam kegiatan belajar dari rumah (BdR) berpengaruh terhadap keaktifan peserta didik kelas XI MAN 1 Jombang, dengan pengaruh sebesar $69,2 \%$. Hal ini dibuktikan dengan hasil F hitung $>\mathrm{F}$ tabel dengan nilai signifikansi $<5 \%$, dan hasil uji autokorelasi Durbin-Watson.

\section{Rekomendasi}

Melihat hasil penelitian tersebut peneliti merekomendasikan agar kinerja wali kelas lebih bagus lagi maka diharapkan memberikan adanya fasilitas kepada lebih berupa paket data internet dan reward. $[\alpha]$

\section{DAFTAR PUSTAKA}

Arikunto, Suharsimi. 2002. Prosedur Penelitian Suatu Pendekatan Praktik. Jakarta: Rineka Cipta.

Djamarah, Syaiful Bahri. 1994. Prestasi Kompetensi Guru. Surabaya: Usaha Nasional.

Koesoema Albertus, Doni. 2007. Pendidikan Karakter Strategi Mendidik Anak di Zaman Global. Jakarta: PT Grasindo.

Nasution, 2006. Metode Research Penelitian IImiah. Jakarta: Bumi Aksara.

Peraturan Menteri Pendidikan Dan Kebudayaan Republik Indonesia Nomor 15 Tahun 2018 Tentang Pemenuhan Beban Kerja Guru, Kepala Sekolah, Dan Pengawas Sekolah.

Sardiman. (2001). Interaksi dan Motivasi belajar Mengajar. Jakarta: Raja Grafindo Persada.

Soetjipto, Raflis Kosasi. 2011. Profesi keguruan. Jakarta : PT Asdi Mahasatya.

Sugiyono, 2018. Statistika untuk Penelitian. Bandung: Alfabeta.

Surat Direktorat J enderal Pendidikan Islam Kementerian Agama Republik Indonesia Nomor B-686.1/ D]. I/ Dt.I.I/ PP.00/03/2020 tentang Mekanisme Pembelajaran dan Penilaian Madrasah dalam Masa Darurat Pencegahan Penyebaran Covid-19.

Yamin, Martinis. 2007. Kiat Membelajarkan Peserta didik. Jakarta: Gaung Persada Press dan Center for Learning Innovation. 